\title{
The Importance of Serum Leptin Level in Chronic Viral Hepatitis B and C
}

\author{
Kronik Viral Hepatit B ve C'de Serum Leptin Düzeyinin Önemi \\ Arzu Şenol ${ }^{1}$ (iD) , Zülal Aşçı Toraman² \\ 1 Department of Infectious Diseases and Clinical Microbiology, Fethi Sekin City Hospital, Elazig/Turkey \\ 2 Department of Clinical Microbiology, Fırat University Faculty of Medicine, Elazig/Turkey
}

\section{özeT}

AMAÇ: Leptin, viral karaciğer hastalıklarında inflamasyon ve karaciğer fibrogenezinde önemli bir rol oynar. Bu çalışmada, kronik hepatit $B(K H B)$ ve kronik hepatit $C(K H C)$ olgularında, serum leptin düzeyini saptamak, leptin düzeylerinin karaciğer inflamasyonu ve fibrozise etkisi değerlendirmek amaçlandı.

GEREÇ VE YÖNTEM: Bu prospektif klinik araştırma çalışmasına, toplam 75 KHB hastası, 36 KHC hastası ve 51 kontrol grubu dahil edildi. Karaciğer biyopsi örnekleri, Ishak histolojik skorlama sistemi kullanılarak skorlandı. Serum leptin düzeyleri, ELISA yöntemi ile belirlendi.

BULGULAR: Kronik hepatit B'li olguların 39'u kadın 36'sı erkek, KHC'li olguların 18'i kadın, 18'i erkek kontrol grubunun ise 26'sı

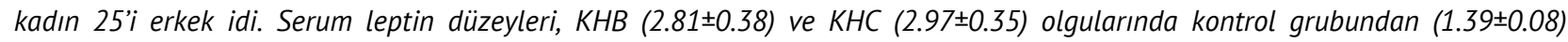
istatistiksel olarak anlamlı yüksekti (p: 0.001). Ancak KHC ve KHB olguları arasında serum leptin düzeyi açısından istatistiksel anlamlı bir farklılık yoktu. Serum leptin düzeyleri ile yaş, cinsiyet, biyokimyasal parametreler arasında istatistiksel anlamlı bir farklılık saptanmadı (P>0.05). Kronik hepatit B ve KHC olgularında belirgin fibrozisi olanlarda, hafif fibrozisi olanlara göre serum leptin düzeyleri istatistiksel olarak anlamlı yüksekti $(P<0.05)$.

SONUÇ: Leptin, KHB ve KHC'de karaciğer inflamasyonu ve fibrozisinde rol oynar. Kronik hepatit B ve KHC olgularında leptin düzeyleri, ileri fibrozis derecesini değerlendirmede ve klinik takipte kullanılabilir, ancak daha geniş çapta çalışmalara ihtiyaç vardır.

Anahtar Kelimeler: Leptin, kronik hepatit B, kronik hepatit C

\section{ABSTRACT}

OBJECTIVE: Leptin plays an important role in inflammation and liver fibrogenesis in viral liver diseases. In this study, determination of serum leptin level and the effect of leptin levels on liver inflammation and fibrosis in chronic hepatitis $B$ (CHB) and chronic hepatitis $\mathrm{C}(\mathrm{CHC})$ cases were evaluated.

MATERIALS AND METHODS: In this prospective clinical research study, a total of 75 CHB patients, 36 CHC patients, and a 51 control group were included. Liver biopsy specimens were scored using Ishak histological scoring system. Serum leptin levels were determined by ELISA method.

RESULTS: Overall, 39 of CHB cases were female while 36 was male, there were 18 female and 18 male cases of CHC, while the control group consisted of 26 female and 25 male. Serum leptin levels were statistically significantly higher in CHB (2.81 \pm 0.38$)$

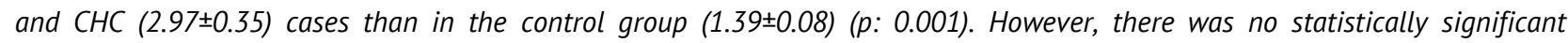
difference in serum leptin level between $\mathrm{CHC}$ and $\mathrm{CHB}$ cases. There was no statistically significant difference between serum leptin levels and age, gender, and biochemical parameters ( $P>0.05)$. Serum leptin levels were statistically significantly higher in patients with significant fibrosis in chronic hepatitis $B$ and KHC patients compared to those with mild fibrosis $(P<0.05)$.

CONCLUSION: Leptin plays a role in liver inflammation and fibrosis in CHB and CHC. In CHB and CHC patients, leptin levels can be used to evaluate the degree of advanced fibrosis and in clinical follow-up, but larger studies are needed.

Keywords: Leptin, chronic hepatitis $B$, chronic hepatitis $C$

\section{INTRODUCTION}

Hepatitis B (HBV) and hepatitis C viruses (HCV) are two important hepatotropic agents that can cause chronic liver disease (CLD) and are widely found worldwide. The most important complication of these infections is the development of liver fibrosis, cirrhosis (LC) and hepatocellular carcinoma (HCC) (1). Hepatitis C virus, which infects approximately 170 million people worldwide, is thought to cause metabolic changes, including steatosis

Yazışma Adresi/Address for Correspondence: Arzu Şenol, MD, Department of Infectious Diseases and Clinical Microbiology, Fethi Sekin City Hospital. Ulukent Neighborhood Onbasi Street No: 99 Elazig, Turkey. Postal zipcode: 23200 Elazig/Turkey

E-Posta/E-Mail: asenol2017@gmail.com || Tel: +90 5052975916

Received/Geliş Tarihi: 14.02.2021 || Accepted/Kabul Tarihi: 18.04.2021

Bu Eser Creative Commons Atıf-Gayriticari 4.0 Uluslararası Lisansı İle Lisanslanmıştır. This work is licensed under a Creative Commons

Attribution-NonCommercial 4.0 International License (CC BY-NC 4.0). 
and steatohepatitis, dyslipidemia, insulin resistance (IR), diabetes, obesity, and cardiovascular events (2).

It is of great importance to show liver fibrosis and its degree in making treatment decisions, determining the prognosis and possible complications in CLD caused by HBV virus and HCV. Although liver biopsy is accepted as the gold standard in the evaluation of liver fibrosis, serum markers that may give an idea about hepatic fibrosis are on the agenda (1). Cytokines and adipokines can affect the development and progression of chronic liver damage, fibrosis / cirrhosis (3). One of the molecules that can be used for this purpose and plays a fibrogenic role in the liver is leptin. Leptin is a polypeptide hormone consisting of 167 amino acids secreted from adipose tissue (1). It is classified as a cytokine because it structurally resembles members of the cytokine family (4).

Leptin is expressed in many organs including the liver. Leptin can induce IR, increase lipid peroxidation and proinflammatory responses. It induces the release of cytokines such as tumor necrosis factor (TNF)-a, interferon (INF)- $y$, interleukin (IL)-18, promotes liver steatosis and fibrosis, and can act as an immunomodulator (5). The prooxidant or antioxidant role of leptin in different tissues is unclear (1). The effect of HCV infection on changes in leptin levels is also unclear (6). In this study, serum leptin levels were determined in chronic hepatitis $\mathrm{B}(\mathrm{CHB})$ and chronic hepatitis $\mathrm{C}(\mathrm{CHC})$ cases and the effect of leptin levels on liver inflammation and fibrosis was evaluated.

\section{MATERIAL \& METHODS}

Study groups: In this prospective clinical research study, a total of $75 \mathrm{CHB}$ patients, $36 \mathrm{CHC}$ patients, and a 51 control group without a history of hepatitis B surface antigen (HBsAg), anti-HCV and anti-HIV negative, acute and chronic hepatitis and any chronic disease who came to the unit of infectious diseases between May 2017 and January 2019, were included. When the study started, $\mathrm{CHB}$ and $\mathrm{CHC}$ patients had not taken any medication.

The demographic data of the cases were recorded retrospectively from electronic patient records. Patients with acute hepatitis, Hepatitis A, Hepatitis C and HIV coinfection, patients whose liver biopsy cannot be performed, patients with positive autoimmune serology, liver diseases due to alcohol use (> $20 \mathrm{~g} /$ day), pregnancy and metabolic and genetic factors, the use of drugs that can cause hepatosteatosis and cases with HCC and LC were excluded.
The diagnosis of $\mathrm{CHB}$ and $\mathrm{CHC}$ was made according to the European Liver Studies Association (EASL) criteria (by laboratory and pathological evaluation) (7).

Data collecting: HBsAg, HBV viral load (HBV DNA), HCV viral load (HCV RNA) serum alanine aminotransferase (ALT) and aspartate aminotransferase (AST), gamma glutamyl transferase (GGT) alpha fetoprotein (AFP), which are part of routine patient analysis levels and liver fine needle aspiration biopsy results were recorded retrospectively. Liver biopsy specimens were scored using the Ishak histological scoring system (fibrosis was assessed out of 6). Chronic Hepatitis B and CHC cases were divided into two groups as prominent fibrosis (Stage 3-4) and mild fibrosis (Stage 1-2) ( there is no stage 5 and 6).

Determination of Serum Leptin Levels: Approximately 5 cc of blood was drawn from the peripheral venous blood from the patients and separated into their serum. Serums were stored at $-80^{\circ} \mathrm{C}$ in a deep freezer. Serums were brought to room temperature and thawed on the working day. Serum leptin levels were determined by ELISA (Enzyme-Linked Immunosorbent Assay) method (R\&D Systems, Minneapolis, MN, USA). Test results are expressed in $\mathrm{ng} / \mathrm{mL}$. The study protocol was in accordance with the Helsinki Declaration of ethics and the study was approved by the University Clinical Research Ethics Committee with the decision number 34 dated 08.06.2017.

\section{Statistical evaluation}

Data analysis procedures were carried out using SPSS 22.0 (Chicago, USA) package statistics software. KolmogorovSmirnow and Shapiro-Wilk normality analysis was performed to determine the conformity of continuous variables to normal distribution. Student's t tests were used in the analysis of continuous variables conforming to normal distribution. "Chi-square test" was used in the analysis of categorical data. Numerical data were expressed as mean \pm standard deviation, and categorical data as $\%$. One-Way ANOVA and Kruskal-Wallis test were used for multiple comparisons. $\mathrm{P}<0.05$ value was accepted as significant in statistical comparisons.

\section{RESULTS}

Overall, 39 of CHB cases were female while 36 was male (age range $43.96 \pm 1.50$ ), there were 18 female and 18 male (age range 51.0 \pm 4.46 ) cases of $\mathrm{CHC}$, while the control group consisted of 26 female and 25 male (age range 29.30 \pm 1.29 ). 
The mean age of $\mathrm{CHB}$ and $\mathrm{CHC}$ patients was statistically significantly higher than the control group. Serum AST, ALT, AFP, cholesterol and triglyceride levels in $\mathrm{CHB}$ and $\mathrm{CHC}$ were higher than the control group. However, it was not statistically significant $(p>0.05)$. Serum leptin levels were statistically significantly higher in $\mathrm{CHB}$ and $\mathrm{CHC}$ cases than in the control group ( $p: 0.001)$. However, there was no statistically significant difference in serum leptin level between $\mathrm{CHC}$ and $\mathrm{CHB}$ cases (p: 0.757) (Human leptin range: $0.313-20 \mathrm{ng} / \mathrm{mL}$, sensitivity: $<0.188 \mathrm{ng} / \mathrm{mL}$ ). The demographic characteristics, laboratory tests and average values of leptin of the $\mathrm{CHB}$ and $\mathrm{CHC}$ cases and the control group are summarized in Table 1.

Table 1. Demographic characteristics of chronic hepatitis $B$ and chronic hepatitis $C$ cases and control group, mean and $p$ values of laboratory tests

\begin{tabular}{|c|c|c|c|c|c|}
\hline & CHB (n: 75) & CHC (n: 36) & Control (n: 51) & p value & p'value \\
\hline Age & $43.96 \pm 1.50$ & $51.0 \pm 4.46$ & $29.30 \pm 1.29$ & 0.001 & \\
\hline Gender (F/M) & $39 / 36$ & $18 / 18$ & $26 / 25$ & 0.923 & \\
\hline Glucose (mg/dL) & $97.74 \pm 3.44$ & $96 \pm 5.25$ & $87.43 \pm 1.97$ & 0.591 & \\
\hline AST (IU/L) & $64.47 \pm 12.06$ & $64.55 \pm 18.02$ & $21.86 \pm 1.791$ & 0.099 & \\
\hline $\mathrm{ALT}(\mathrm{IU} / \mathrm{L})$ & $104.04 \pm 21.11$ & $93.36 \pm 26.57$ & $22.57 \pm 1.69$ & 0.053 & \\
\hline Total Bilirubin & $0.62 \pm 0.06$ & $0.89 \pm 0.26$ & $0.34 \pm 0.03$ & 0.131 & \\
\hline $\operatorname{AFP}(\mu / L)$ & $2.97 \pm 0.59$ & $6.46 \pm 1.14$ & $2.76 \pm 0.37$ & 0.107 & \\
\hline PTZ (sn) & $12.70 \pm 0.46$ & $12.43 \pm 0.38$ & $11.09 \pm 0.13$ & 0.403 & \\
\hline HBV DNA $\left(10^{3}\right) \mathrm{IU} / \mathrm{mL}$ & $73447 \pm 3.36$ & & & & \\
\hline HCV RNA $\left(10^{3}\right) I \mathrm{I} / \mathrm{mL}$ & & $3954.3 \pm 2.24$ & & & \\
\hline $\operatorname{cOL}(\mathrm{mg} / \mathrm{dL})$ & $180.27 \pm 11.99$ & $174.83 \pm 19.41$ & $147.14 \pm 5.33$ & 0.548 & \\
\hline TRG (mg/dL) & $138.95 \pm 18.89$ & $98.60 \pm 20.43$ & $77.14 \pm 2.86$ & 0.128 & \\
\hline Leptin ( $\mathrm{ng} / \mathrm{ml})$ & $2.81 \pm 0.38$ & $2.97 \pm 0.35$ & $1.39 \pm 0.08$ & 0.028 & 0.001 \\
\hline
\end{tabular}

CHB: Chronic hepatitis B, CHC: Chronic hepatitis C, COL: Cholesterol, TRG: Triglyceride, AST: Aspartate aminotransferase, ALT: Alanine aminotransferase, AFP: Alpha feto protein, PTZ: Prothrombin time, $p$ 'value: CHB-control group, P value between CHC-control group (Kruskal-Wallis test) F: female, M: male, n: number of patients, HBV DNA: Hepatitis B Virus DNA replication count, HCV RNA: Hepatitis C Virus RNA replication count

No statistically significant difference was found between serum leptin levels and age, gender, AST, ALT, AFP, cholesterol, triglyceride, HBV DNA and HCV RNA values ( $p>$ 005). Serum leptin levels were significantly higher in patients with significant fibrosis in $\mathrm{CHB}$ and $\mathrm{CHC}$ patients compared to those with mild fibrosis $(p<005)$. AFP levels in chronic hepatitis $C$ cases were significantly higher in those with significant fibrosis ( $\mathrm{p}<005)$. ALT, AFP, HBV DNA, HCV RNA and leptin levels are shown in Table 2 according to the fibrosis score in $\mathrm{CHB}$ and $\mathrm{CHC}$ patients.

Table 2. Alanine aminotransferase, alpha fetoprotein, HBV DNA, HCV RNA and leptin levels in chronic hepatitis B and chronic hepatitis $C$ cases according to the fibrosis score

\begin{tabular}{|r|ccc|ccc|}
\hline & \multicolumn{3}{|c|}{ Chronic hepatitis B } & \multicolumn{3}{c|}{ Chronic hepatitis C } \\
& $\begin{array}{r}\text { Mild Fibrosis } \\
\text { (Stage 1-2) (N: 37) }\end{array}$ & $\begin{array}{c}\text { Significant Fibrosis } \\
\text { (Stage 3-4) (N: 43) }\end{array}$ & p value & Mild Fibrosis & Significant Fibrosis & $p$ value \\
(Stage 1-2) (N: 37) & (Stage 3-4) (N: 43) & \\
ALT $(\mathrm{IU} / \mathrm{L})$ & $2,00 \pm 0.09$ & $4.55 \pm 1.01$ & 0.001 & $1.35 \pm 0.22$ & $3.46 \pm 0.43$ & 0.006 \\
AFP $(\mathrm{H} / \mathrm{L})$ & $20.21 \pm 14.44$ & $170.79 \pm 63.57$ & 0.625 & $60.75 \pm 18.94$ & $146.40 \pm 47.52$ & 0.110 \\
HBV DNA $\left(10^{3}\right) \mathrm{IU} / \mathrm{mL}$ & $60110 \pm 35195$ & $33530 \pm 91353$ & 0.400 & & $7.27 \pm 1.25$ & 0.032 \\
HCV RNA $\left(10^{3}\right) \mathrm{IU} / \mathrm{mL}$ & & & & $245720 \pm 225990$ & $3022900 \pm 180695$ & 0.101 \\
\hline
\end{tabular}

ALT: Alanine aminotransferase, AFP: Alpha feto protein, HBV DNA: Hepatitis B Virus DNA replication count, HCV RNA: Hepatitis C Virus RNA replication count $N$ : number of patients

\section{DISCUSSION}

Cytokines play an important role in the coordination of processes such as liver growth and regeneration, inflammatory events such as viral liver disease, fibrosis and cirrhosis (8). In this study, serum leptin levels and the relationship of leptin with liver fibrosis in $\mathrm{CHB}$ and $\mathrm{CHC}$ cases were evaluated. One study showed that women have higher leptin levels than men. This study reported that leptin has a profibrogenic role and increases hepatic steatosis, inflammation, and fibrosis. It was also stated that 
leptin could be a marker for disease severity. However, the mechanisms of fibrogenesis are not yet clear (9). It has been stated that in chronic viral hepatitis, serum leptin levels are affected by the age and gender of the patients. In this study, leptin levels were reported to be higher in women than in men (3).

It has been shown that the progression of fibrosis is rapid, and gender affects the incidence and progression of liver diseases in elderly HCV-infected patients. Women infected with the HCV develop decompensated disease less frequently (10). In this study, the mean age of CHB and $\mathrm{CHC}$ cases was higher than the control group. However, no statistically significant difference was found between serum leptin levels and age and gender in $\mathrm{CHB}, \mathrm{CHC}$ and control groups, inconsistent with the study results. Adiponectin and leptin are the most studied adipokines to date, and several reports have been published on their effects on the liver. In addition, leptin is known to contribute to fibrogenesis in chronic liver diseases (10).

The role of leptin, an important adipokine, in liver fibrogenesis has been demonstrated (3). One study showed that serum levels of leptin may be associated with the severity of hepatic steatosis and fibrosis (11). No significant association was found between serum leptin and liver fibrosis in 7 of 12 studies among chronic viral hepatitis cases. Multivariate analysis results in chronic viral hepatitis showed that serum leptin could not predict the stage of liver fibrosis. Three studies found a positive association between serum leptin and liver fibrosis, while two studies did not find such an association. In addition, it has been shown that serum leptin levels may be affected by the gender, age, genetic diversity of the cases, and hereditary or non-hereditary diseases and should be considered in future studies (3).

In a study, it was shown that leptin level increased in CHB and $\mathrm{CHC}$ cases associated with fibrosis (1). In another study, it has been suggested that the leptin system plays a role in immunopathogenesis in patients with chronic viral hepatitis, and the increased leptin production in the inflammatory process stimulates CD4 T lymphocytes and macrophages, leading to cytokine release. In $\mathrm{CHC}$ cases, high serum leptin levels were found, but no relationship was determined between the degree of fibrosis and leptin. A positive relationship was shown between leptin and IL-6, but no relationship was found between HBV DNA and leptin
(8). It has been found that leptin levels are not associated with HCV RNA (6). In this study, there was no significant correlation between serum leptin level and viral load between $\mathrm{CHB}$ and $\mathrm{CHC}$ cases ( $p>0.05)$.

In cases of $\mathrm{CHC}$, blood leptin levels have been found to be associated with the degree of fibrosis (12). In addition, leptin levels in $\mathrm{CHC}$ were found to be high in severe hepatic fibrosis and it was found that leptin levels increased as the level of fibrosis increased. The number of studies investigating the relationship between HBV infection and leptin is less than HCV infection (8). In cases of $\mathrm{CHC}$, higher serum leptin levels have been associated with the presence of steatosis (4). In a study conducted on 30 patients infected with the HCV, it was observed that the fatty acids of proinflammatory cytokines disrupted mitochondrial $\beta$ oxidation and could lead to steatohepatitis progressing to liver damage (13). Serum leptin levels were higher in 30 patients with $\mathrm{CHC}$ than in 30 controls, and leptin levels were independently associated with the severity of fibrosis.

In a univariate analysis, leptin levels were found to be associated with steatosis but not with necroinflammation or fibrosis in $74 \mathrm{CHC}$ cases. Although serum leptin levels are increased in patients with $\mathrm{CHC}$, data on their association with histological lesions are quite contradictory. This study may be due to heterogeneity in populations (14). It has been suggested that $\mathrm{CHC}$ cases have higher serum leptin levels than HCV negative controls (15). In the study of Aşçı et al., leptin level was found to be higher in $\mathrm{CHC}$ cases than the control group. However, no relationship was found between the degree of fibrosis and leptin. In cases with $\mathrm{CHB}$, serum leptin levels were not different from the control group.

The number of studies investigating the relationship between HBV infection and leptin is more limited than HCV infection (16). The results of the studies are contradictory. In some studies, no significant relationship was found between serum leptin levels and liver fibrosis in cases with $\mathrm{CHB}$, while some were found to be associated with liver fibrosis (8). The relationship between leptin and hepatic fibrosis in the course of liver disease associated with HCV infection is controversial. In vitro studies have demonstrated the role of leptin in profibrogenic responses in the liver. However, it showed that there is no relationship between serum leptin and fibrosis in HCV infection. 
The reason for this discrepancy is not clear (12). Studies have reported that serum leptin levels are significantly high in $\mathrm{CHC}$ cases and leptin levels may be determinant in severe hepatic fibrosis. It was found that as the level of fibrosis increased, the leptin levels also increased. The results of the studies conducted in $\mathrm{CHB}$ cases are contradictory. In some studies, there was no significant relationship between serum leptin levels in liver fibrosis in patients with $\mathrm{CHB}$, while in others, serum leptin levels were found to be increased in the presence of liver fibrosis compared to the healthy control group (16). In another study, leptin was found to be associated with the presence of hepatic fibrosis in CHB patients (17). It has been shown that leptin is only associated with the degree of steatosis, but not with fibrosis (9).

In some studies, it has been shown that leptin level increases in $\mathrm{CHB}$ and $\mathrm{CHC}$ patients associated with fibrosis (1). In one study, increased leptin levels were found in patients with $\mathrm{CHC}$ compared to healthy controls. Conflicting results have been given about the possible role of leptin in fibrogenesis (18). Clarifying the mechanisms of action of leptin and similar cytokines is important for investigating the genetic basis of multifunctional diseases caused by these molecules (4). In this study, serum leptin level in CHB and $\mathrm{CHC}$ cases was higher than the control group (p: 0.001). However, no statistically significant difference was found between $\mathrm{CHB}$ and $\mathrm{CHC}$ cases in terms of leptin levels ( $p$ > 0.05). However, in $\mathrm{CHB}$ and $\mathrm{CHC}$ cases, serum leptin levels were significantly higher in those with significant fibrosis than those with mild fibrosis (p: 0.001, p: 0.006, respectively).

This study had some limitations. Cases with hepatosteatosis, HCC and LC were not included in the study. In addition, insulin resistance and body mass index were not evaluated.

Conclusion: Although the role of leptin in $\mathrm{CHB}$ and $\mathrm{CHC}$ does not appear to be clear yet, it may play a prominent role in liver inflammation and fibrogenesis. In this study, serum leptin level and whether this parameter can be used in place of histopathological examination of the liver were investigated. Leptin may indicate fibrosis as an indicator of fibrosis but may not be useful in determining the degree of fibrosis. With the available data, it does not seem possible to reach a definitive conclusion about the relationship between leptin and liver fibrosis. Therefore, more studies are needed to determine whether leptin is an appropriate parameter for evaluating fibrosis in $\mathrm{CHB}$ and $\mathrm{CHC}$ cases.

Etik: Bu çalışmanın etik kurulu alınmıştır (08.06.2017/34).

Ethics committee approval had been taken (08.06.2017/34).

Yazar katkı durumu; Çalışmanın konsepti; AŞ dizaynı; ZAT Literatür taraması; AŞ verilerin toplanması ve işlenmesi; ZAT istatistik; AŞ yazım aşaması; AŞ

Author contribution status; The concept of the study; AŞ design; ZAT literature review; AŞ collecting and processing data; ZAT statistics; AŞ writing phase; AŞ

Yazarlar arasında çıkar çatışması yoktur.

The author declares no conflict of interest.

Finansal Destek: yoktur / Funding: none

doi: https://doi.org/10.33713/egetbd. 880183

\section{REFERENCES}

1. Zeybekoğlu G, Kılıç N, Yıldırım Z, Özer Ç, Babül A. Effects of leptin in rat liver antioxidant systems. Turkish Journal of Biochemistry. 2012; 37 (4): 452-456.

2. Chang ML, Kuo CJ, Huang HC, Chu YY, Chiu CT. Association between Leptin and Complement in Hepatitis C Patients with Viral Clearance: Homeostasis of Metabolism and Immunity. PLOS ONE. 2016; 11(11): 1-12.

3. Haghgoo SM, Sharafi H, Alavian SM. Serum cytokines, adipokines and ferritin for non-invasive assessment of liver fibrosis in chronic liver disease: a systematic review. Clin Chem Lab Med. 2019; 57(5): 577-610.

4. Keleş $V$, Büyükgüzel $K$, Büyükgüzel $E$. Leptin and Role in Metabolic RegulationTurkish Journal of Diabetes and Obesity. 2018; 1: 17-22.

5. Pavlidis C, Panoutsopoulos GI, Tiniakos D, Koutsounas $S$, Vlachogiannakos J, Vafiadis IZ. Serum leptin and ghrelin in chronic hepatitis C patients with steatosis. World J Gastroenterol. 2011; 17(46): 5097-5104.

6. Chang ML, Kuo CJ, Huang HC, Chu YY, Chiu CT. Association between Leptin and Complement in Hepatitis C Patients with Viral Clearance: Homeostasis of Metabolism and Immunity. PLOS ONE.2016; 11(11): 1-12.

7. European Association for the Study of the Liver. Electronic address: easloffice@easloffice.eu; European Association for the Study of the Liver. EASL 2017 Clinical Practice Guidelines on the management of hepatitis B virus infection. J Hepatol. 2017 Aug; 67(2): 370-398. doi: 10.1016/j.jhep.2017.03.021. Epub 2017 Apr 18. PMID: 28427875.

8. Balkan A, Gülşen MT, Balkan Y, Çalı SK. Relationship between the frequency of hepatitis $B$ virüs infections and levels of serum adipokines in patients with hepatosteatosis and insulin resistance. $\quad$ Eur J Ther. 2017; 23: 60-6. 
9. Rotundo L, Persaud A, Feurdean M, Ahlawat S, Kim HS. The association of leptin with severity of non-alcoholic fatty liver disease: A population-based study Clinical and Molecular Hepatology. 2018; 24: 392-401.

10. Buechler C, Haberl EM, Fischboeck LR, Aslanidis C. Adipokines in Liver Cirrhosis. International Journal of Molecular Sciences. Int. J. Mol. Sci. 2017; 18: 1392.

11. Polyzos SA, Aronis KN, Kountouras J, Raptis DD, Vasiloglou MF, Mantzoros CS. Circulating leptin in non-alcoholic fatty liver disease: a systematic review and meta-analysis. Diabetologia. 2016; 59: 30-43.

12. Korah TE, Sayed SE, ElShafie MK, Hammoda GE, Safan MA. Significance of serum leptin and adiponectin levels in Egyptian patients with chronic hepatitis C virus associated hepatic steatosis and fibrosis. World J Hepatol. 2013; 5(2): 74-81.

13. Reimers EG, Platt GQ, Gaspar MR, Valls RA, Hernández OP, Fernández FS. Liver steatosis in hepatitis $C$ patients. World J Hepatol. 2015; 7(10): 1337-1346.

14. Altıntaş E, Aslan G, Sezgin O, Üçbilek E, Emektar G, Gezer D. Increased serum leptin concentration is related to steatosis in hepatitis C virus-infected patients. Academic journal of gastroenterology. 2011; 10 (3): 97-103.

15. Khattab MA, Eslam $M$, Shatat $M$, et al. Changes in Adipocytokines and Insulin Sensitivity during and after Antiviral Therapy for Hepatitis C Genotype 4. J Gastrointestin Liver Dis. 2012; 21(1): 59-65.

16. Aşçı Z, Demirtürk N, Demirdal T, et al. Predictive Value of Serum Fibrosis Markers with Liver Histopathology in Patients with Chronic Viral Hepatitis. Turkey Clinics J Med Sci. 2012; 32(6): 1569-75.

17. Kumar R, Prakash S, Chhabra S, et al. Association of proinflammatory cytokines, adipokines \& oxidative stress with insulin resistance \& non-alcoholic fatty liver disease. Indian J Med Res. 2012; 136: 229-236.

18. Kukla M, Mazur W, Buldak RJ, Korczala KZ. Potential Role of Leptin, Adiponectin and Three Novel Adipokines-Visfatin, Chemerin and Vaspin in Chronic Hepatitis. Mol Med. 2011; 17 (11-12): 1397- 1410. 